prof. dr hab. inż. Jerzy Merkisz,

dr inz. Lukasz Rymaniak

dr hab. inz Piotr Lijewski, prof. PP

mgr inz. Michalina Kamińska

dr inz. Beata Kurc

Politechnika Poznańska

\title{
Tests of ecological indicators of two-way vehicles meeting Stage IIIB and Stage IV standards in real operating conditions
}

\section{Badania wskaźników ekologicznych pojazdów dwudrogowych spelniających standardy Stage IIIB i Stage IV w rzeczywistych warunkach eksploatacji}

\begin{abstract}
The article presents the tests and analysis of ecological indicators of two rail-road tractors carried out during the real operation. The conditions of tests and vehicle constructions were characterized by the similar parameters, while the objects met the different exhaust gas emission standards: Stage IIIB and Stage IV. Apparatus from the PEMS group was used in the tests. In the analysis of ecological indicators, the unit emission of harmful gaseous compounds and particulates was determined. The supplementation is the assessment of toxicity indicators, which are the reference of individual compounds to $\mathrm{CO}_{2}$ emission. More favourable ecological characteristics were obtained by a vehicle meeting the newer exhaust gas emission standard, which resulted mainly from the use of advanced exhaust gas treatment systems in its construction.
\end{abstract}

$W$ artykule zaprezentowano badania $i$ analizę wskaźników ekologicznych dwóch ciagników szynowo-drogowych zrealizowane podczas rzeczywistej eksploatacji. Warunki testów i konstrukcje pojazdów charakteryzowaty się zbliżonymi parametrami, przy czym obiekty spetniaty odmienne normy emisji spalin: Stage IIIB i Stage IV. W badaniach zastosowano aparature $z$ grupy PEMS. W analizie wskaźników ekologicznych wyznaczono jednostkowq emisję szkodliwych zwiazków gazowych i czq̨stek stałych. Uzupetnienie stanowi ocena wskaźników toksyczności, będacych odniesieniem poszczególnych zwiqzków do emisji $\mathrm{CO}_{2}$. Korzystniejsze charakterystyki ekologiczne uzyskat pojazd spetniajacy nowsza norme emisji spalin, co wynikało przede wszystkim z zastosowania w jego konstrukcji zaawansowanych uktadów oczyszczania spalin.

\section{INTRODUCTION}

The operation of machines and vehicles equipped with the internal combustion engines is connected with the emission of toxic compounds into the atmosphere. For several decades, the restrictions of various kinds regarding the ecological indicators limits in the various test conditions have been introduced in most regions/countries of the world. For the motor vehicles of PC class (Passanger Car), the limits expressed in the road emissions of pollutants are applicable, while for the heavy duty vehicles, the unit emission standards are applicable. Currently, in Europe in both cases the tests, which are carried out in the real operating conditions, are applicable, at least for checking the conformity in operation.

For off-road vehicles, the approval tests carried out only on the engine dynamometer are still in force. The brake measurements are to simulate in some range the

\section{WPROWADZENIE}

Eksploatacja maszyn i pojazdów wyposażonych w silniki spalinowe jest związana $\mathrm{z}$ emisją związków toksycznych do atmosfery. Od kilkudziesięciu lat $\mathrm{w}$ większości regionów/krajów świata wprowadzane są różnego rodzaju obostrzenia dotyczące limitów wskaźników ekologicznych w różnych warunkach testowych. Dla pojazdów samochodowych klasy PC (Passanger Car) obowiązują limity wyrażone w emisji drogowej zanieczyszczeń, natomiast dla pojazdów ciężkich (Heavy Duty Vehicle) obowiązują standardy emisji jednostkowej. Obecnie w Europie w obydwu przypadkach obowiązują testy wykonywane w rzeczywistych warunkach eksploatacji, przynajmniej dla kontroli zgodności w eksploatacji.

Dla pojazdów pozadrogowych cały czas obowiązują badania homologacyjne realizowane wyłącznie na hamowni silnikowej. Pomiary hamulcowe mają w 
conditions of actual engine operation, but they are far from the actual parameters of their use. As proven in many scientific papers $[6,7]$ the carried out cycles are definitely different from the real operating conditions. Therefore, it is not possible to make the accurate analysis of their actual impact on the environment and human health. The NRMM (Non-Road Mobile Machinery) group includes a number of machines characterized by the different construction and purpose (from combustion saws to shunting locomotives). As proven in papers $[6,7,11,12]$ for obtaining the reliable ecological indicators of the specific machines and vehicles, it is necessary to carry out the tests in the real operating conditions. It allows to determine the emission in a wide spectrum of machines and drive systems of vehicles and allows to determine the conformity of their operation referring to the relevant approval standards. Such activities also allow taking into account the local environmental conditions.

The producers of machines and motor vehicles currently focus their activities primarily on reducing the negative impact on the environment. They realize this mainly by introducing the new technologies in supply systems and non-engine exhaust gas treatment systems. The development of the off-road machines industry allows to look for the new areas of application for increasingly advanced constructions already produced. An example of such a treatment is the creation of two-way vehicles and putting them into service. These are agricultural tractors adapted to the standard and rail operation. Their functionality and economics of operation allow their wider use not only on the railways but also in the complicated storage systems. Two-way vehicles are becoming more and more common, therefore it is necessary to take research actions in the field of their impact on the natural environment by determining the ecological indicators.

\section{LEGAL REGULATIONS CONCERNING MEASUREMENT OF EXHAUST GAS EMIS- SIONS IN TWO-WAY VEHICLES}

Currently, in the European Union, vehicles and NRMM machines are tested in two test cycles for which limits of unit emission of pollutants are defined [14]. In both cases, the measurements are carried out in the laboratory conditions on the engine dynamometer. Procedures and limits are described in the next standards defined as Stage I-V. The first Stage standards came into force in 1999.

The first of the cycles is the NRSC (Non-Road Stationary Cycle) test, which determines the emission of pollutants at the specific engine operating points. It is carried out in standards for ZS engines with a net power of $19 \mathrm{~kW} \leq \mathrm{P}$ operating at constant rotational speed and load. The test consists of a number of phases of rotational speed and load covering the typical operating range of ZS engines used in off-road vehicles. During each of the tested phases, the pewnym zakresie symulować warunki rzeczywistej pracy silnika, jednak są one dalekie od faktycznych parametrów ich użytkowania. Jak udowodniono w wielu pracach naukowych [6, 7] przeprowadzane cykle zdecydowanie różnią się od realnych warunków eksploatacji. W związku z tym nie jest możliwe dokonanie rzetelnej analizy dotyczącej ich faktycznego wpływu na środowisko i zdrowie ludzi. Do grupy NRMM (Non-Road Mobile Machinery) zakwalifikowanych jest szereg maszyn charakteryzujących się różną konstrukcją i przeznaczeniem (od pił spalinowych do lokomotyw manewrowych). Jak dowiedziono w pracach $[6,7,11,12]$ dla uzyskania miarodajnych wskaźników ekologicznych konkretnych maszyn i pojazdów, konieczne jest przeprowadzanie testów w rzeczywistych warunkach eksploatacji. To pozwala wyznaczyć emisję w szerokim spektrum pracy maszyn i pojazdów układów napędowych oraz pozwalaja określić zgodność ich eksploatacji odnoszącej się do odpowiednich norm homologacyjnych. Takie działania pozwalają również uwzględnić lokalne warunki otoczenia.

Producenci maszyn i pojazdów silnikowych ukierunkowuja obecnie swoje działania przede wszystkim na ograniczenie negatywnego wpływu na środowisko naturalne. Realizują to głównie przez wprowadzanie nowych technologii w układy zasilania oraz pozasilnikowe układy oczyszczania spalin. Rozwój branży maszyn pozadrogowych pozwala szukać nowych obszarów zastosowania dla coraz bardziej zaawansowanych konstrukcji już produkowanych. Przykładem takiego zabiegu jest stworzenie i wprowadzenie do eksploatacji pojazdów dwudrogowych. Są to ciagniki rolnicze dostosowane do eksploatacji standardowej i szynowej. Ich funkcjonalność i ekonomia eksploatacji pozwalają na coraz szersze ich wykorzystanie nie tylko na kolei, ale i w skomplikowanych systemach magazynowania. Pojazdy dwudrogowe stają się coraz powszechniejsze, w związku z czym konieczne jest podejmowanie działań poznawczych $\mathrm{w}$ zakresie ich wpływu na środowisko naturalne, poprzez określenie wskaźników ekologicznych.

\section{REGULACJE PRAWNE DOTYCZACCE POMIARU EMISJI SPALIN W POJAZDACH DWUDROGOWYCH}

Aktualnie w Unii Europejskiej pojazdy i maszyny NRMM badane są w dwóch cyklach testowych, dla których zdefiniowane są limity emisji jednostkowej zanieczyszczeń [14]. W obu przypadkach pomiary są prowadzone $\mathrm{w}$ warunkach laboratoryjnych na hamowniach silnikowych. Procedury i limity opisane sa w kolejnych standardach określonych jako Stage I-V. Pierwsze normy Stage zaczęły obowiązywać w 1999 roku.

Pierwszym z cykli jest test NRSC (Non-Road Stationary Cycle), w którym określa się emisję zanieczysz- 
concentration of tested harmful exhaust gas, their flow rate as well as power and weighted average measured values are determined. They are tested continuously during a set sequence of operating conditions of the warmed up engine.

With introduction of Stage IIIB and IV standards, the NRTC (Non-Road Transient Cycle) dynamic test began to apply. It is a cycle in which the engine works in the wide spectrum of variability of operating parameters (Fig. 1). The emissions are measured not only at definite points, but also in transitional states. Two cycles are performed during the test. The cycle of cold start consists in conditioning of the engine at $20 \div 30^{\circ}$ C. It is implemented after natural or forced cooling of the engine. The cycle of hot start is carried out in a warmed state, 20 minutes after conditioning, immediately after the end of the first cycle. The total emission of harmful compounds in the exhaust gas is obtained during the test. The work generated by the engine throughout the entire cycle is determined by integrating the power in relation to the cycle time, using the torque feedback signals and rotational speed of dynamometer brake.

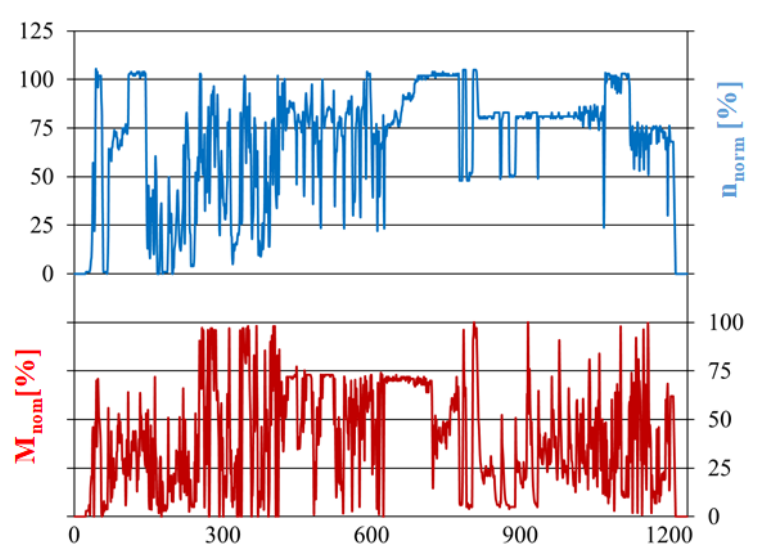

t [s]

Rys. 1. Charakterystyka testu homologacyjnego NRTC dla maszyn pozadrogowych [5]

Fig. 1. Characteristic of the NRTC approval test for off-road machines [5]

\section{METHODOLOGY OF TESTS}

The ecological indicators of two rail-road tractors were assessed in the tests. Their constructions were similar to each other, but they met the different standards of pollutant emission: object I - Stage IIIB standard and object II - Stage IV standard (Fig. 2).

The first tested object was equipped with a drive unit with a maximum power of $116 \mathrm{~kW}$, characterized by a maximum torque of $659 \mathrm{Nm}$. The other machine had the same power, but the rated torque was smaller and reached the value of $640 \mathrm{Nm}$. In addition, the tested object II was equipped with exhaust gas treatment systems - DOC (Diesel Oxidation Catalyst), SCR (Selective Catalytic Reduction) and DPF (Diesel Par- czeń w określonych punktach pracy silnika. Przeprowadza się go w standardach dla silników ZS o mocy netto $19 \mathrm{~kW}$ ? P pracujących przy stałej prędkości obrotowej i obciążeniu. Test składa się z pewnej liczby faz prędkości obrotowej i obciążenia, pokrywających typowy zakres pracy silników ZS stosowanych w pojazdach pozadrogowych. Podczas każdej z badanych faz określa się stężenie badanych związków szkodliwych spalin, ich natężenie przepływu oraz moc i średnie ważone zmierzonych wartości. W trakcie ustalonej sekwencji warunków pracy rozgrzanego silnika badane są one w sposób ciagły.

Wraz z wprowadzeniem standardów Stage IIIB i IV zaczął obowiązywać test dynamiczny NRTC (NonRoad Transient Cycle). Jest to cykl, w którym silnik pracuje w szerokim spektrum obszaru zmienności parametrów pracy (rys. 1). Pomiar emisji jest realizowany nie tylko $\mathrm{w}$ określonych punktach, ale także w stanach przejściowych. Podczas testu wykonuje się dwa cykle. Cykl zimnego rozruchu polega na przeprowadzeniu kondycjonowania silnika w temperaturze $20 \div 30{ }^{\circ} \mathrm{C}$. Realizowany jest on po naturalnym lub wymuszonym ochłodzeniu silnika. Cykl gorącego rozruchu wykonywany jest w stanie nagrzanym, 20 minut po kondycjonowaniu, bezpośrednio po zakończeniu pierwszego cyklu. Podczas badania otrzymuje się całkowitą wielkość emisji związków szkodliwych w spalinach. Pracę wytworzoną przez silnik w całym cyklu określa się poprzez całkowanie mocy względem czasu cyklu, wykorzystując do tego sygnały sprzężenia zwrotnego momentu obrotowego i prędkości obrotowej hamulca dynamometrycznego.

\section{METODYKA BADAŃ}

W badaniach dokonano oceny wskaźników ekologicznych dwóch ciagników szynowo-drogowych. Ich konstrukcje były zbliżone do siebie, przy czym spełniały różne standardy emisji zanieczyszczeń: obiekt I - standard Stage IIIB oraz obiekt II - standard Stage IV (rys. 2).

Pierwszy obiekt badany wyposażony był w jednostkę napędową o mocy maksymalnej $116 \mathrm{~kW}$, charakteryzujący się maksymalnym momentem obrotowym wynoszącym $659 \mathrm{Nm}$. Druga maszyna posiadała taką samą moc, jednak znamionowy moment obrotowy był mniejszy i osiagał wartość $640 \mathrm{Nm}$. Dodatkowo II obiekt badany wyposażony był w układy oczyszczania spalin - DOC (Diesel Oxidation Catalyst), SCR (Selective Catalytic Reduction) oraz DPF (Diesel Particulate Filter). Szczegółowe dane techniczne przedstawiono w tablicy 1 . W konstrukcji pojazdów zastosowano szereg rozwiązań technicznych pozwalających na ich poruszanie się po szynach kolejowych, z zachowaniem możliwości eksploatacji drogowej i poligonowej. Wśród najważniejszych można wymienić: zestaw kół szynowych wraz z systemem ich opuszczania (dociskania) i podnoszenia, układ hamul- 
ticulate Filter). The detailed technical data are presented in Table 1. A number of technical solutions were used in the construction of vehicles allowing them to move on the railway rails with maintaining the possibility of road and field operation. The most important ones include: a set of rail wheels with their lowering (pressing) and lifting systems, braking system and draw and buffer elements. An important parameter is also the permissible total weight, which allows the tractor to move on the public roads [10].

The vehicles are dedicated to the implementation of shunting works with the freight, passenger wagons, locomotives, as well as traction units. The main purpose of their application is to improve the economic indicators in this type of works with simultaneous reducing the negative impact on the natural environment in comparison with the traditional shunting locomotives $[2,8]$. The measurements were made under the typical operating conditions of test objects during traveling on tracks with a load of 20 tons (rolling the wagon). Before starting the tests their technical condition was checked and the condition of on-board diagnostic systems was controlled.

The technically advanced apparatus classified to PEMS (Portable Emissions Measurement Systems) group was used in the tests. The measurements included both the gaseous compounds $\left(\mathrm{CO}_{2}, \mathrm{CO}, \mathrm{HC}\right.$, $\mathrm{NO}_{\mathrm{X}}$ ), and solid particles (PM). The Axion R/S+ device was used in the first tested object, but Smetech DS with the AVL Micro Soot Sensor was used in the second one (Table 2). The exhaust gas flow rate was determined with the concentration of toxic compounds. At the same time, the data from on-board diagnostic systems, GPS signal, as well as information on the current weather conditions were recorded. The device also measured the current atmospheric conditions (pressure, temperature and humidity) in order to introduce the corrections during the processing of recorded data $[1,3,15]$. All data was recorded with a frequency of $1 \mathrm{~Hz}$. cowy oraz elementy zderzeniowo-zaczepne. Istotnym parametrem jest również dopuszczalna masa całkowita, która umożliwia poruszanie się ciagnika po drogach publicznych [10].

Pojazdy dedykowane są do realizacji prac manewrowych z wagonami towarowymi, osobowymi, lokomotywami, a także zespołami trakcyjnymi. Głównym celem ich zastosowania jest poprawa wskaźników ekonomicznych $\mathrm{w}$ tego typu pracach, $\mathrm{z}$ jednoczesnym zmniejszeniem negatywnego oddziaływania na środowisko naturalne, w porównaniu do tradycyjnych lokomotyw manewrowych $[2,8]$. Pomiary wykonano w typowych warunkach eksploatacji obiektów badawczych, podczas przejazdu po torach z obciążeniem 20 ton (przetaczanie wagonu). Przed rozpoczęciem testów sprawdzono ich stan techniczny oraz dokonano kontroli stanu pokładowych systemów diagnostycznych.

Zestawienie parametrów konstrukcyjnych badanych obiektów $[9,16]$ Tablica 1

List of constructional parameters of tested objects $[9,16]$ Table 1

\begin{tabular}{|l|l|l|}
\hline \multicolumn{1}{|c|}{$\begin{array}{l}\text { Parametr/ } \\
\text { Parameter }\end{array}$} & $\begin{array}{c}\text { Obiekt I/ } \\
\text { Object I }\end{array}$ & $\begin{array}{c}\text { Obiekt } \\
\text { II/ } \\
\text { Object II }\end{array}$ \\
\hline $\begin{array}{l}\text { Moc maksymalna [kW]/ } \\
\text { Maximum power [kW] }\end{array}$ & 116 & 116 \\
\hline $\begin{array}{l}\text { Max. moment obrotowy [Nm]/ } \\
\text { Max. torque [Nm] }\end{array}$ & 659 & 640 \\
\hline $\begin{array}{l}\text { Norma emisji spalin/ } \\
\text { Standard of exhaust gas emis- } \\
\text { sion }\end{array}$ & Stage IIIB & Stage IV \\
\hline $\begin{array}{l}\text { Max. siła uciagu na torze [kN]/ } \\
\text { Max. tractive effort on the track } \\
{[\mathrm{kN}]}\end{array}$ & 35 & 45 \\
\hline $\begin{array}{l}\text { Masa pojazdu [t]/ } \\
\text { Vehicle mass [t] }\end{array}$ & 9 & 8.2 \\
\hline $\begin{array}{l}\text { Max. prędkość jazdy [km/h]/ } \\
\text { Max. travel speed [km/h]/ }\end{array}$ & 23 & 25 \\
\hline $\begin{array}{l}\text { Max. prędkość jazdy po torze } \\
{[\mathrm{km} / \mathrm{h}] / \text { Max. speed on track }} \\
{[\mathrm{km} / \mathrm{h}]}\end{array}$ & 23 & 25 \\
\hline $\begin{array}{l}\text { Układy oczyszczania spalin/ } \\
\text { Exhaust gas treatment systems }\end{array}$ & DOC & $\begin{array}{l}\text { DOC, } \\
\text { SCR, } \\
\text { DPF }\end{array}$ \\
\hline
\end{tabular}

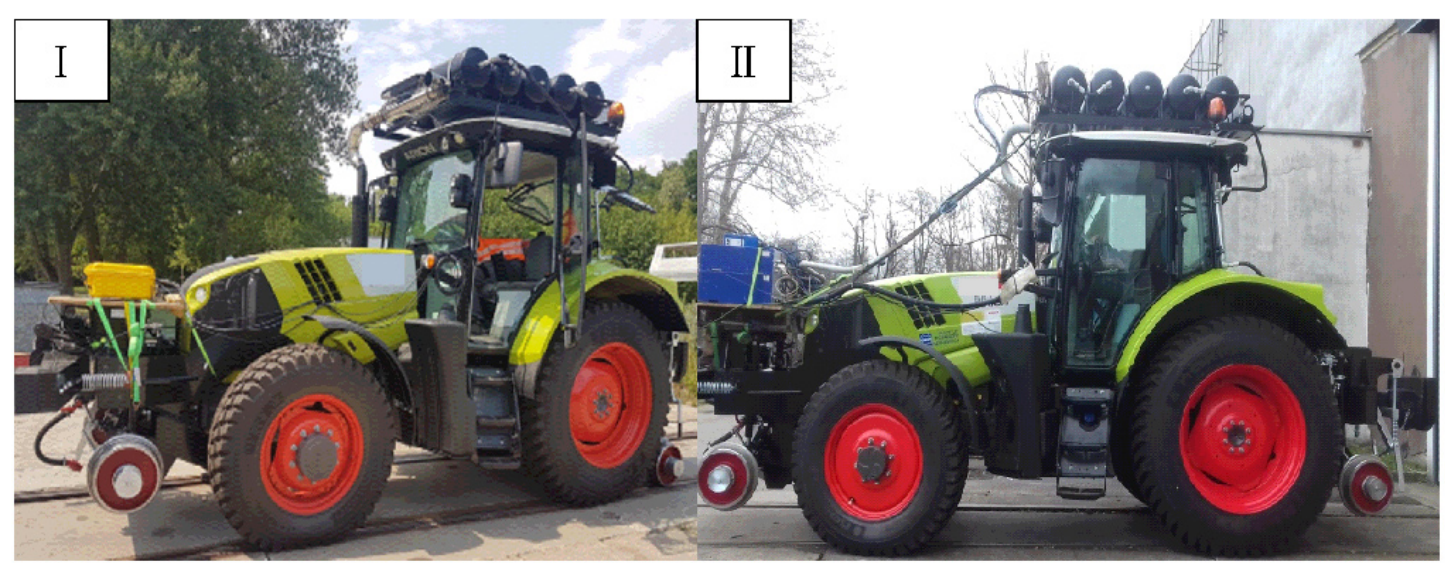

Rys. 2. Badane obiekty: I - ciagnik szynowo-drogowy (Stage IIIB), II - ciagnik szynowo-drogowy (Stage IV) Fig. 2. Tested objects: I - rail-road tractor (Stage IIIB), II - rail-road tractor (Stage IV) 
Dane techniczne mobilnych przyrządów pomiarowych $[1,3,15]$ Tablica 2

Technical data of mobile measuring devices $[1,3,15] \quad$ Table 2

\begin{tabular}{|l|l|l|l|l|l|}
\hline $\begin{array}{c}\text { Związek } \\
\text { szkodliwy/ } \\
\text { Harmful } \\
\text { compound }\end{array}$ & \multicolumn{2}{|c|}{$\begin{array}{c}\text { Zakres pomiarowy/ } \\
\text { Measurement range }\end{array}$} & $\begin{array}{c}\text { Rozkład/ } \\
\text { Resolution }\end{array}$ & \multicolumn{2}{c|}{$\begin{array}{c}\text { Metoda pomiaru/ } \\
\text { Measurement method }\end{array}$} \\
\hline & Axion R/S+ & Smetech DS & & Axion R/S + & Smetech DS \\
\hline $\mathrm{HC}$ & $0-4000 \mathrm{ppm}$ & $0-10000 \mathrm{ppm}$ & $1 \mathrm{ppm}$ & NDIR & FID \\
\hline $\mathrm{CO}$ & $0-10 \%$ & $0-10 \%$ & 0,01 obj. $\%$ & NDIR & NDIR \\
\hline $\mathrm{CO}_{2}$ & $0-16 \%$ & $0-20 \%$ & 0,01 obj. $\%$ & NDIR & NDIR \\
\hline $\mathrm{NO}_{\mathrm{x}}$ & $0-4000 \mathrm{ppm}$ & $0-3000 \mathrm{ppm}$ & $1 \mathrm{ppm}$ & E-chem & NDUV \\
\hline $\mathrm{O}_{2}$ & $0-25 \%$ & $0-21 \%$ & 0,01 obj. $\%$ & E-chem & E-chem \\
\hline & Axion R/S + & Smetech DS & & Axion R/S + & AVL MSS \\
\hline $\mathrm{PM}$ & $0-300 \mathrm{mg} / \mathrm{m}^{3}$ & $0-50 \mathrm{mg} / \mathrm{m}^{3}$ & $0,01 \mathrm{mg} / \mathrm{m}^{3}$ & Laser Scatter & Fotoakustyczna/Photoacoustic \\
\hline
\end{tabular}

\section{RESULTS OF TESTS}

To assess the toxicity indicators in the real operating conditions, it is useful to carry out the analysis of the movement parameters of the tested objects and the operation of their drive systems. The courses of speed in both travels were similar and their average values were $5.4 \mathrm{~km} / \mathrm{h}$ and $3.7 \mathrm{~km} / \mathrm{h}$ respectively (Fig. 3). The maximum speed of tractor meeting the Stage IIIB reached $8.8 \mathrm{~km} / \mathrm{h}$, while for the second tested object it was $11.5 \mathrm{~km} / \mathrm{h}$. The main assumption in made travels was to achieve the same total work by the drive system. This condition was met and in both cases 2.5 $\mathrm{kWh}$ was achieved. To accomplish this, the tested objects covered a route with length of about $1 \mathrm{~km}$. Obtaining the same total work over a similar distance resulted from the similar construction of tested objects and the application of the same load. The presented course of dependence indicates that a significant increase in work occurs not only during acceleration, but also during standstill. First of all the braking system had the impact on this (connected with the PTO system), which significantly charges the internal combustion engine during filling (air compression).

On the basis of recorded data, the shares of working time in the speed and acceleration ranges were determined (Fig. 4). The one-sided closed ranges were determined for precise determination of driving ranges. The parking share of the tested objects was $15 \%$ and $18 \%$, respectively. For driving at a constant speed (acceleration $=0 \mathrm{~m} / \mathrm{s}^{2}$ ) the working time was $27.6 \%$ for the first tested object. In the second cycle, this value reached $15.8 \%$. The significant shares of working time were obtained during braking of vehicle, especially in the deceleration range $<-0.3 \mathrm{~m} / \mathrm{s}^{2} ; 0$ $\mathrm{m} / \mathrm{s}^{2}$ ) for speed of $0.5 \mathrm{~m} / \mathrm{s} ; 2 \mathrm{~m} / \mathrm{s}>$, which were respectively $42.8 \%$ and $40.7 \%$. The significant values for the discussed range of work resulted from the characteristics of the measuring route, namely in certain ranges it was characterized by the significant decreases, which required a greater proportion of braking. This directly reflected in increasing the
W badaniach wykorzystano zaawansowaną technicznie aparaturę klasyfikowaną do grupy PEMS (Portable Emissions Measurement Systems). W pomiarach uwzględniono zarówno związki gazowe $\left(\mathrm{CO}_{2}, \mathrm{CO}\right.$, $\mathrm{HC}, \mathrm{NO}_{\mathrm{X}}$ ), jak i cząstki stałe (PM). W pierwszym obiekcie badawczym użyto przyrządu Axion R/S+, natomiast w drugim wykorzystano Smetech DS wraz z AVL Micro Soot Sensor (tab. 2). Wraz ze stężeniem związków toksycznych wyznaczano natężenie przepływu gazów wylotowych. Jednocześnie rejestrowane były dane z pokładowych systemów diagnostycznych, sygnał GPS, a także informacje o aktualnych warunkach atmosferycznych. Przyrząd dokonywał również pomiaru aktualnych warunków atmosferycznych (ciśnienie, temperatura i wilgotność) w celu wprowadzenia korekcji podczas przetwarzania zarejestrowanych danych [1, 3, 15]. Wszystkie dane zapisywane były z częstotliwością $1 \mathrm{~Hz}$.

\section{WYNIKI POMIARÓW}

Do oceny wskaźników toksyczności w rzeczywistych warunkach eksploatacji przydatne jest przeprowadzenie analiz parametrów ruchu badanych obiektów oraz pracy ich układów napędowych. Przebiegi prędkości w obydwu przejazdach były do siebie zbliżone, a ich średnie wartości wyniosły odpowiednio $5,4 \mathrm{~km} / \mathrm{h}$ oraz $3,7 \mathrm{~km} / \mathrm{h}$ (rys. 3). Prędkość maksymalna ciągnika spełniającego normę Stage IIIB osiagnęła wartość 8,8 $\mathrm{km} / \mathrm{h}$, natomiast dla drugiego obiektu badanego wynosiła $11,5 \mathrm{~km} / \mathrm{h}$. Głównym założeniem w realizowanych przejazdach było uzyskanie takiej samej pracy sumarycznej przez układ napędowy. Warunek ten został spełniony i w obu przypadkach osiagnięto 2,5 $\mathrm{kWh}$. Aby to zrealizować, obiekty badawcze pokonały trasę o długości około $1 \mathrm{~km}$. Uzyskanie takiej samej całkowitej pracy na podobnym dystansie wynikało ze zbliżonej konstrukcji obiektów badawczych i zastosowania takiego samego obciążenia. Przedstawiony przebieg zależności wskazuje, że znaczny przyrost pracy występuje nie tylko podczas przyspieszania, ale również w trakcie postoju. Wpływ na to 
charge on the internal combustion engine by the air compressor to supply the braking system. miał przede wszystkim układ hamulcowy (połączony z układem WOM), który podczas ładowania (sprężania powietrza) znacznie obciąża silnik spalinowy.
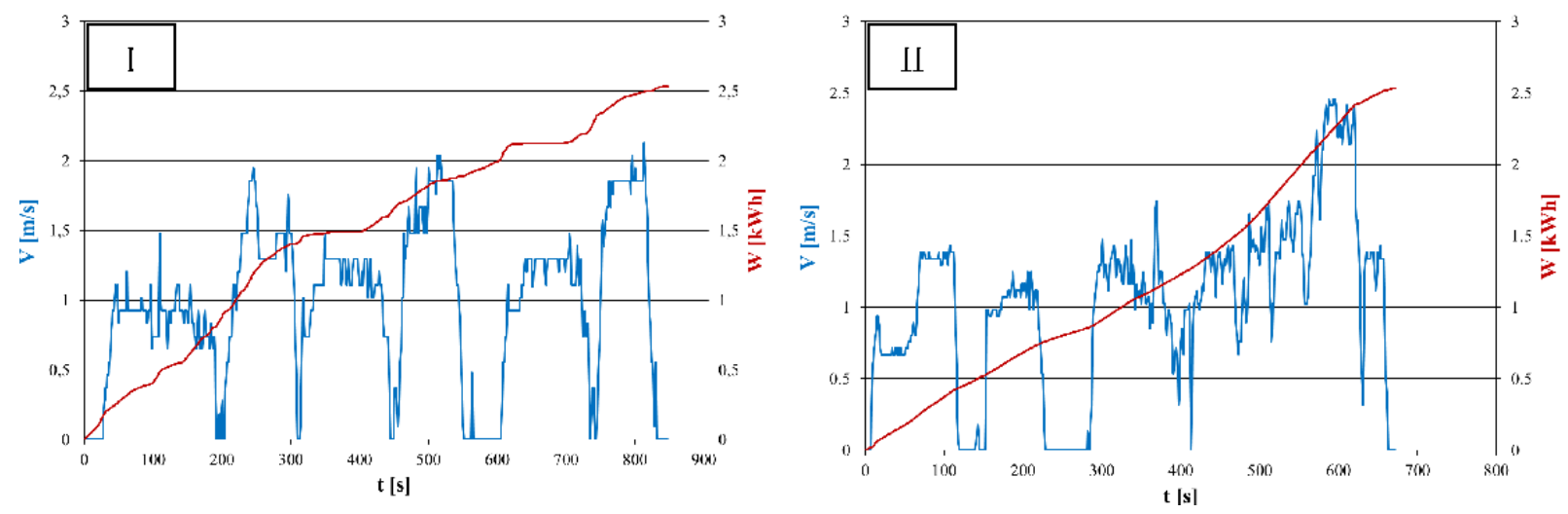

Rys. 3. Przebiegi prędkości badanych obiektów oraz sumarycznej pracy ich silników spalinowych podczas przejazdu w rzeczywistych warunkach ruchu: I - ciagnik szynowo-drogowy (Stage IIIB), II - ciagnik szynowo-drogowy (Stage IV) Fig. 3. Speed courses of tested objects and the total work of their internal combustion engines during travel in real traffic conditions: I - rail-road tractor (Stage IIIB), II - rail-road tractor (Stage IV)
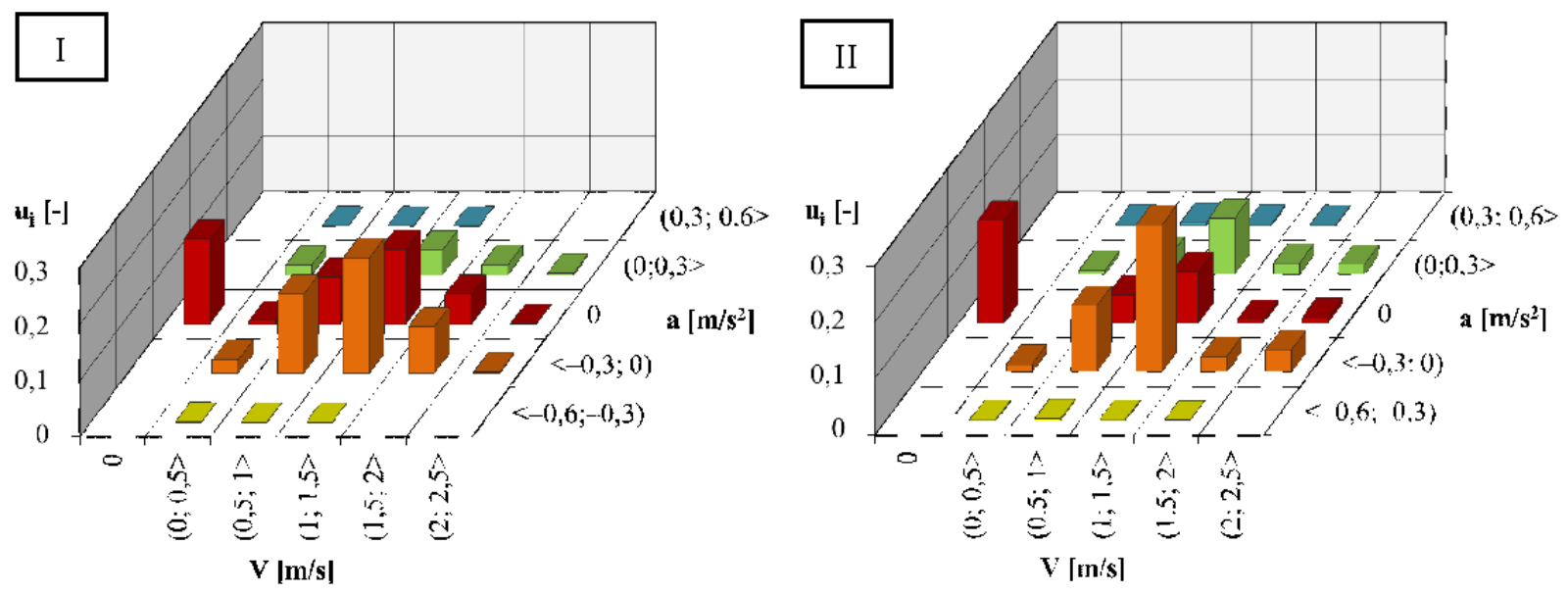

Rys. 4. Udziały czasu pracy badanych obiektów w rzeczywistych warunkach ruchu w przedziałach prędkości i przyspieszenia: I - ciagnik szynowo-drogowy (Stage IIIB), II - ciągnik szynowo-drogowy (Stage IV)

Fig. 4. Shares of working time of tested objects in real traffic conditions in speed and acceleration ranges: I - rail-road tractor (Stage IIIB), II - rail-road tractor (Stage IV)

After analyzing the movement parameters of the tested objects and the operation of their drive systems, the analysis of vehicle toxicity indicators in the real operating conditions was performed (Fig. 5). Due to the applied exhaust gas treatment systems in the second tested object, more favourable unit emission indicators were obtained for $\mathrm{NO}_{\mathrm{x}}$ and $\mathrm{PM}$. The relative differences for the first vehicle were $43.8 \%$ and $78.1 \%$, respectively. The lower indicators of $0.19 \mathrm{~g} /$ $\mathrm{kWh}$ were also achieved for unit $\mathrm{CO}$ emissions. The rail-road tractor meeting the Stage IV standard had the worse parameters of $\mathrm{HC}$ emissions. In this case, the relative difference was $3 \%$ and in total was 0.32 $\mathrm{g} / \mathrm{kWh}$. Referring the obtained data to the approval standards (limits defined in Stage IIIB and IV) it can be found that the indicators are within the standard for $\mathrm{CO}$ (both vehicles) and PM (vehicle II). In other
Na podstawie zarejestrowanych danych wyznaczono udziały czasu pracy w przedziałach prędkości i przyspieszenia (rys. 4). Dla precyzyjnego określenia zakresów jazdy wyznaczono przedziały jednostronnie domknięte. Udział postoju obiektów badanych wyniósł odpowiednio $15 \%$ i $18 \%$. Dla jazdy ze stała prędkością (przyspieszenie $=0 \mathrm{~m} / \mathrm{s}^{2}$ ) czas pracy stanowił $27,6 \%$ dla pierwszego obiektu ba-dawczego. W drugim cyklu wartość ta osiagnęła $15,8 \%$. Znaczące udziały czasu pracy uzyskano podczas hamowania pojazdów, szczególnie $\mathrm{w}$ zakresie opóźnienia $<-0,3$ $\mathrm{m} / \mathrm{s}^{2} ; 0 \mathrm{~m} / \mathrm{s}^{2}$ ) dla prędkości $0,5 \mathrm{~m} / \mathrm{s} ; 2 \mathrm{~m} / \mathrm{s}>$, które wyniosły kolejno $42,8 \%$ i 40,7\%. Znaczne wartości dla omawianego zakresu pracy wynikały $\mathrm{z}$ charakterystyki drogi pomiarowej, mianowicie $\mathrm{w}$ pewnych zakresach charakteryzowała się ona znacznymi spadkami, co wymagało większego udziału hamowania. 
cases, exceeding the limits was up to four times (object I; PM emission). First of all the conditions of test influenced this, which were significantly different from the approval guidelines, as presented it in the article. In addition, CF (Conformity Factor) coefficients, which have not been defined for the considered emission standards, are used during comparison of the indicators obtained in real and laboratory conditions for PC and HDV vehicles.

A number of harmful compounds are formed in the engine during combustion. This is due to the complexity of this process and its uniqueness. At present, many modern engine and non-engine construction measures are used in modern drive units to reduce this phenomenon. Considering the development of drive systems related to the introduction of further emission standards, a significant reduction of ecological indicators was obtained, in some cases exceeding more than $95 \%\left(\mathrm{NO}_{\mathrm{x}}, \mathrm{PM}\right)[13]$. This is achieved by introducing advanced exhaust gas treatment systems, including DPF or SCR [4].

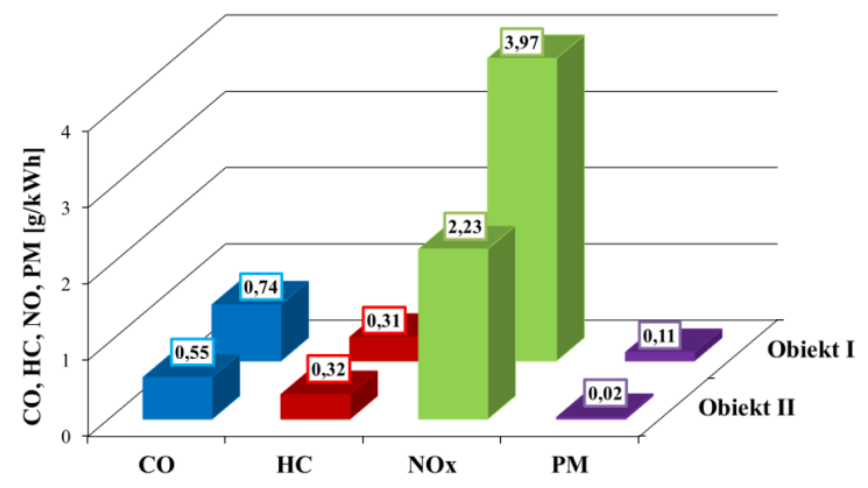

Rys. 5. Emisja jednostkowa związków toksycznych spalin badanych obiektów: I - ciągnik szynowo-drogowy (Stage IIIB), II ciągnik szynowo-drogowy (Stage IV)

Fig. 5. Unit emission of toxic compounds of exhaust gases of tested objects: I - rail-road tractor (Stage IIIB), II - rail-road tractor (Stage IV)

Referring to the basic chemical equations of the combustion process, it is assumed that $\mathrm{CO}_{2}$ is a product of complete and total combustion and it can be considered as a measure of the correctness of this process realization. At the same time, it is directly proportional to fuel consumption. Therefore, it is possible to use it for the ecological assessment of the object. Reference of a given toxic compound to $\mathrm{CO}_{2}$ allows to set the new toxicity indicators. For this purpose, it is necessary to use the $\mathrm{M}$ quantitative toxicity indicator, which is defined by the quotient:

$$
\mathrm{M}_{\mathrm{j}}=\mathrm{b} \cdot \frac{\mathrm{e}_{\text {rzecz, } \mathrm{j}}}{\mathrm{e}_{\mathrm{CO}_{2}}}
$$

where:

M - bezwymiarowy wskaźnik toksyczności [-]/dimensionless toxicity indicator [-]

$j$ - zwiqzek toksyczny, dla którego wyznaczono wskaźnik emisjil toxic compound for which the emission indicator was determined
To bezpośrednio przekładało się na zwiększenie obciążenia silnika spalinowego przez sprężarkę powietrza w celu zasilenia układu hamulcowego.

Po przeprowadzeniu analiz parametrów ruchu badanych obiektów oraz pracy ich układów napędowych, wykonano analizę wskaźników toksyczności pojazdów w rzeczywistych warunkach eksploatacji (rys. 5). Ze względu na zastosowane układy oczyszczania spalin $\mathrm{w}$ drugim obiekcie badanym, korzystniejsze wskaźniki emisji jednostkowej uzyskano dla $\mathrm{NO}_{\mathrm{x}}$ oraz PM. Różnice względne w odniesieniu do pierwszego pojazdu wyniosły odpowiednio 43,8\% i 78,1\%. Mniejsze wskaźniki o $0,19 \mathrm{~g} / \mathrm{kWh}$ osiagnięto również dla emisji jednostkowej CO. Ciagnik szynowodrogowy spełniający norme Stage IV cechował się gorszymi parametrami emisji HC. W tym przypadku różnica względna wyniosła 3\% i sumarycznie wynosiła $0,32 \mathrm{~g} / \mathrm{kWh}$. Odnosząc uzyskane dane do norm homologacyjnych (limitów zdefiniowanych w Stage IIIB i IV) można stwierdzić, że wskaźniki mieszczą się w normie dla CO (obydwa pojazdy) oraz PM (pojazd II). W pozostałych przypadkach przekroczenie limitów było nawet czterokrotne (obiekt I; emisja PM). Wpływ na taki stan rzeczy miały przede wszystkim warunki testu, które znacznie różniły się od wytycznych homologacyjnych, tak jak przedstawiono to w artykule. Ponadto podczas porównywania wskaźników uzyskanych w warunkach rzeczywistych i laboratoryjnych dla pojazdów PC oraz HDV stosowane są współczynniki CF (Conformity Factor), które nie zostały zdefiniowane dla rozpatrywanych norm emisyjnych.

W silniku podczas spalania powstaje szereg związków szkodliwych. Wynika to ze złożoności tego procesu i jego niepowtarzalności. Obecnie w nowoczesnych jednostkach napędowych stosowanych jest wiele skutecznych środków konstrukcyjnych silnikowych i pozasilnikowych, służących zmniejszeniu tego zjawiska. Biorąc pod uwagę rozwój układów napędowych związany $\mathrm{z}$ wprowadzaniem kolejnych standardów emisyjnych, uzyskano znaczace zmniejszenie wskaźników ekologicznych, w niektórych przypadkach przekraczające ponad $95 \%\left(\mathrm{NO}_{\mathrm{x}}, \mathrm{PM}\right)$ [13]. Osiagane jest to przez wprowadzanie zaawansowanych systemów oczyszczania spalin, m.in. DPF czy SCR [4].

Odnosząc się do podstawowych równań chemicznych procesu spalania, przyjmuje się że $\mathrm{CO}_{2}$ jest produktem spalania zupełnego oraz całkowitego i można go uznać jako miarę poprawności realizacji tego procesu. Jednocześnie jest on wprost proporcjonalny do zużycia paliwa. Możliwe jest zatem wykorzystanie go do oceny ekologicznej obiektu.- Odniesienie danego związku toksycznego do $\mathrm{CO}_{2}$ pozwala ustalić nowe wskaźniki toksyczności. W tym celu konieczne jest wykorzystanie ilościowego wskaźnika toksyczności M, który definiowany jest ilorazem: 
$b$ - stata uniwersalna (dla CO, THC $i N O_{X}=10^{3}$, dla $P M=$ $10^{5}$ )/ universal constant (for CO, THC and $N O_{X}=10^{3}$, for $P M$ $=10^{5}$ )

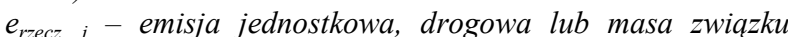
toksycznego $j$ wyznaczona podczas badań w teście $[\mathrm{g} /(\mathrm{kW} \cdot \mathrm{h})$; $\mathrm{g} /(\mathrm{km}) ; \mathrm{g}] \mathrm{l}] /$ unit, road or mass emission of toxic compound $j$ determined in the tests $[\mathrm{g} /(\mathrm{kW} \cdot \mathrm{h}) ; \mathrm{g} /(\mathrm{km}) ; \mathrm{g} /]$

$e_{\mathrm{CO} 2}$ - emisja jednostkowa, drogowa lub masa $\mathrm{CO}_{2}$ wyznaczona podczas badań $w$ teście (tożsama $z \quad e_{\text {rzecz, }}$ ) $[\mathrm{g} /(\mathrm{kW} \cdot \mathrm{h}) ; \mathrm{g} /(\mathrm{km}) ; \mathrm{g}]$ /unit emissions, road emissions or $\mathrm{CO}_{2}$ mass determined during the tests (equivalent to $e_{r z e c z, j}$ ) $[\mathrm{g} /(\mathrm{kW} \cdot \mathrm{h}) ; \mathrm{g} /(\mathrm{km}) ; \mathrm{g}]$.

The proposed indicator is dimensionless and it can be especially useful in the considerations regarding the field tests of off-road vehicles (Fig. 6). This is due to the operating conditions of these machines, the frequent stops and short covered distances. In this type of measurements there are also the problems with determining the operating parameters from the onboard diagnostic systems, especially in the machines of older generation. The dimensionlessness of discussed indicator is also a good method for determining the amount of toxic compound emissions in relation to the fuel consumption.

Based on the obtained results of toxicity indicators, it can be found that the values keep the similar tendencies as in the unit emission analysis. This results from the very similar construction of objects and test conditions. The unit emission $\mathrm{CO}_{2}$ of the vehicle I was $1202.4 \mathrm{~g} / \mathrm{kWh}$, but for the second solution a more favourable result was obtained, which was lower by $63 \mathrm{~g} / \mathrm{kWh}$. The presented characteristics also indicates the significant operation of exhaust gas treatment systems. The SCR and DPF systems used in the second rail-road tractor made the reduced emissions, and thus they improved the ecological balance, which results from the obtained toxicity indicators.

\section{SUMMARY}

Two-way vehicles gain more and more popularity due to their multi-tasking and operating economics. They are classified into the group of off-road vehicles, so the approval of their power units is carried out only on engine dynamometers in the laboratory conditions. Due to the development of test methods and measuring apparatus, the legislative procedures covering the actual operation are used for the increasing number of vehicle types. Such activities are also planned in the vehicles of the NRMM group. The presented results of tests and the works carried out by other scientific centers prove that such activities are necessary in order to actual assessment of the ecological indicators of the considered group of machines.

The constructions of tested objects and conditions of carried out tests were similar, however, object II obtained more favourable ecological indicators due to the applied exhaust gas treatment systems. In addition to DOC, it used DPF and SCR. Only the emission of $\mathrm{HC}$ was worse in comparison with the first tested
Zaproponowany wskaźnik jest bezwymiarowy i może być szczególnie przydatny w rozważaniach dotyczących badań poligonowych pojazdów pozadrogowych (rys. 6). Wynika to $\mathrm{z}$ warunków eksploatacji tych maszyn, częstych postojów i małych pokonywanych dystansów. W tego typu pomiarach występują również problemy $\mathrm{z}$ określeniem parametrów pracy $\mathrm{z}$ pokładowych systemów diagnostycznych, szczególnie w maszynach starszej generacji. Bezwymiarowość omawianego wskaźnika stanowi również dobrą metodę określania wielkości emisji związków toksycznych w odniesieniu do zużycia paliwa.

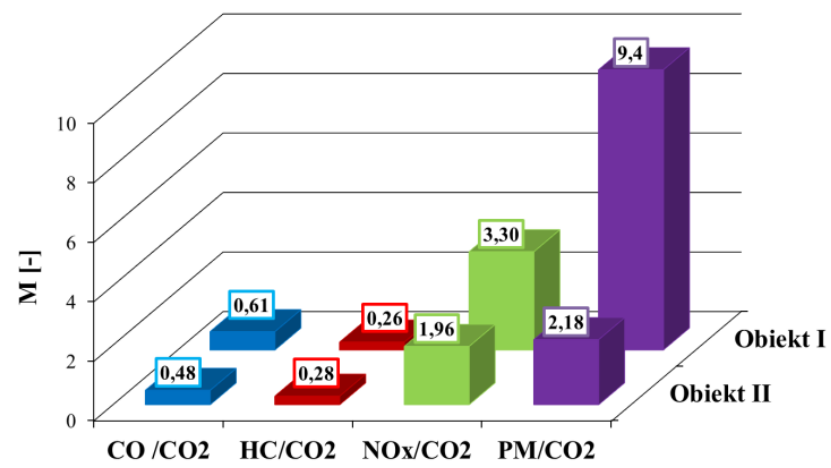

Rys. 6. Zestawienie wskaźników toksyczności M dla CO, HC, $\mathrm{NO}_{\mathrm{X}}$ oraz PM: I - ciągnik szynowo-drogowy (Stage IIIB), II ciagnik szynowo-drogowy (Stage IV)

Fig. 6. List of $\mathrm{M}$ toxicity indicators for $\mathrm{CO}, \mathrm{HC}, \mathrm{NO}_{\mathrm{X}}$ and PM: I rail-road tractor (Stage IIIB), II - rail-road tractor (Stage IV)

$\mathrm{Na}$ podstawie uzyskanych wyników wskaźników toksyczności można stwierdzić, że wartości zachowuja podobne tendencje jak $\mathrm{w}$ analizie emisji jednostkowej. Wynika to $\mathrm{z}$ bardzo zbliżonych konstrukcji obiektów i warunków testowych. Emisja jednostkowa $\mathrm{CO}_{2}$ pojazdu I wyniosła $1202,4 \mathrm{~g} / \mathrm{kWh}$, natomiast dla drugiego rozwiązania uzyskano korzystniejszy wynik, mniejszy o $63 \mathrm{~g} / \mathrm{kWh}$. Przedstawiona charakterystyka również wskazuje istotne działanie układów oczyszczania spalin. Systemy SCR i DPF zastosowane w drugim ciagniku szynowo-drogowym spowodowały ograniczenie emisji, a tym samym poprawiły bilans ekologiczny, co wynika z uzyskanych wskaźników toksyczności.

\section{PODSUMOWANIE}

Pojazdy dwudrogowe zyskują coraz większą popularność ze względu na ich wielozadaniowość i ekonomie eksploatacji. Klasyfikowane są do grupy pojazdów pozadrogowych, a więc homologacja ich zespołów napędowych realizowana jest wyłącznie na hamowniach silnikowych w warunkach laboratoryjnych. Ze względu na rozwój metod badawczych i aparatury pomiarowej, dla coraz większej liczby typów pojazdów stosowane są procedury legislacyjne obejmujące rzeczywistą eksploatację. Takie działania planowane są również w pojazdach grupy NRMM. Zaprezentowane wyniki badań i prace prowadzone przez inne 
object, but the difference was not significant, because it was about $3 \%$. Carrying out the tests on the longer routes at the different loads will be the development of the presented tests. At the same time, it is planned to supplement the tests with the dimensional and numerical decomposition of solid particles, which is currently a very important issue in the aspect of the problem of the impact of motorization on the natural environment.

The research was funded by European Union from European Regional Development Fund through the National Centre for Research and Development (Narodowe Centrum

Badań i Rozwoju) - research project within the Smart

Growth Programme (contract No. POIR.04.01.02-00$0002 / 18)$.

Badania zostały sfinansowane przez Unię Europejską z

Europejskiego Funduszu Rozwoju Regionalnego za pośrednictwem Narodowego Centrum Badań i Rozwoju projekt badawczy w ramach programu Inteligentny Rozwój (umowa nr POIR.04.01.02-00-0002/18). ośrodki naukowe dowodzą, że takie działania są konieczne w celu rzeczywistej oceny wskaźników ekologicznych rozpatrywanej grupy maszyn.

Konstrukcje obiektów badanych i warunki prowadzonych testów były zbliżone, jednak korzystniejsze wskaźniki ekologiczne uzyskał obiekt II, ze względu na zastosowane układy oczyszczania spalin. Oprócz DOC zastosowano w nim DPF i SCR. Gorzej ukształtowała się wyłączne emisja $\mathrm{HC}$ w porównaniu do pierwszego obiektu badawczego, przy czym różnica nie była znacząca, ponieważ stanowiła ok. 3\%. Rozwinięciem przedstawionych badań stanowić będzie wykonanie testów na dłuższych trasach przy zróżnicowanym obciążeniu. Jednocześnie planuje się uzupełnienie badań o rozkład wymiarowy i liczbowy cząstek stałych, co obecnie stanowi bardzo istotne zagadnienie $\mathrm{w}$ aspekcie problemu wpływu motoryzacji na środowisko naturalne.
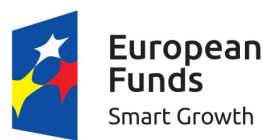
Funds Smart Growth

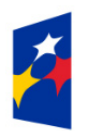

Fundusze Europejskie Inteligentny Rozwój

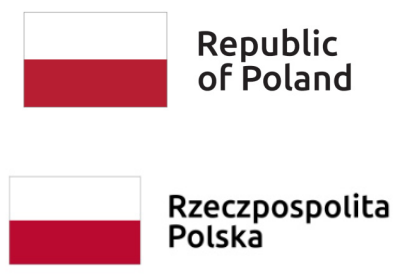

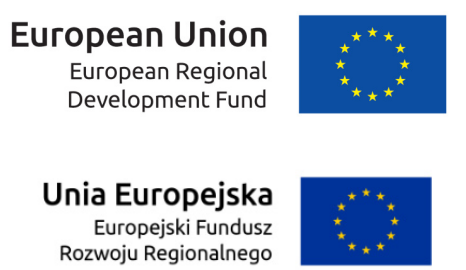

Unia Europejska
Europejski Fundusz Rozwoju Regionalnego

\section{Bibliography / Bobliografia}

1. AVL List GmbH. Micro Soot Sensor. Transient High Sensitive Soot Measurement. Graz 2010.

2. Daszkiewicz P.,Andrzejewski M.: Preliminary analyzes in terms of the possibility of reducing energy consumption by the SM42 locomotive used in track works, MATEC Web of Conferences, Vol. 118, EDP Sciences, 2017.

3. GlobalMRV Inc. AxionRS+. Introducing the world's first Micro PEMS with remote monitoring capabilities, Cheektowaga 2017.

4. Fuć P., Lijewski P., Sokolnicka B., Siedlecki M., Szymlet N.: Analysis of Exhaust Gas Flow Through a Particulate Filter in the Exhaust of the Spark Ignition Direct Injection Engine, AIP Conference Proceedings, Vol. 2078, No. 1, AIP Publishing LLC, 2019.

5. Lijewski P.: Studium emisji zwiqzków toksycznych spalin z silników o zastosowaniu pozadrogowych, Rozprawa habilitacyjna nr 516, Wydawnictwo Politechniki Poznańskiej, Poznań 2013.

6. Lijewski P., Merkisz J., Fuć P., Kozak M., Rymaniak L: Air pollution by the exhaust emissions from construction machinery under actual operating conditions, Applied Mechanics and Materials, Vol. 390, pp. 313-319). Trans Tech Publications, 2013.

7. Kamińska M., Rymaniak E., Daszkiewicz P., Lijewski P.: Test guidelines for evaluation real driving emission two-way vehicles. MATEC Web of Conferences, 294, 02009-1-02009-8, Lviv, Ukraine 2019.

8. $\quad$ Marciniak Z., Stawecki W., Merkisz J., Pielecha I., Pielecha J.: Możliwości modyfikacji taboru spalinowego w celu zmniejszenia jego oddziaływania na środowisko naturalne, Technika Transportu Szynowego, 3/2011.

9. Materiaty producentów pojazdów rolniczych.

10. Medwid M., Stawecki W., Czerwiński J., Jakuszko W.: Wielozadaniowy ciagnik szynowo-drogowy nowej generacji, Pojazdy Szynowe $3 / 2016$

11. Merkisz J., Lijewski P., Fuć P, Siedlecki M, Ziolkowski A.: Development of the methodology of exhaust emissions measurement under RDE (Real Driving Emissions) conditions for non-road mobile machinery (NRMM) vehicles, IOP Conference Series: Materials Science and Engineering, Volume 148, Scientific Conference on Automotive Vehicles and Combustion Engines (KONMOT 2016) 22-23 September 2016, Krakow, Poland.

12. Merkisz J., Pielecha J, Fuć P., Lijewski P.: The analysis of the PEMS measurements of the exhaust emissions from city buses using different research procedures, 2012 IEEE Vehicle Power and Propulsion Conference, 2012.

13. Merkisz J., Rymaniak E.: . The assessment of vehicle exhaust emissions referred to CO2 based on the investigations of city buses under actual conditions of operation, Eksploatacja i Niezawodność - Maintenance and reliability 2017; 19 (4): 522-529, http://dx.doi.org/10.17531/ein.2017.4.5.

14. ROZPORZADZENIE PARLAMENTU EUROPEJSKIEGO I RADY (UE) 2016/1628 z dnia 14 września 2016 r. w sprawie wymogów dotyczqcych wartości granicznych emisji zanieczyszczeń gazowych i pyłowych oraz homologacji typu w odniesieniu do silników spalinowych wewnętrznego spalania przeznaczonych do maszyn mobilnych nieporuszajacych sie po drogach, zmieniajace rozporzqdzenia (UE) nr 1024/2012 i (UE) nr 167/2013 oraz zmieniajqce i uchylajace dyrektywę 97/68/WE.

15. STEDMAN, D.H., BISHOP, G., MCLAREN, S. Apparatus for remote analysis of vehicle emissions. U.S. Patent No 5498872, 1996.

16. http://transportszynowy.pl [dostęp: 04.05.2020] 